\title{
Manufacturing hollow obturator with resilient denture liner on post hemimaxillectomy
}

\author{
Michael Josef Kridanto Kamadjaja \\ Department of Prosthodontia \\ Faculty of Dentistry Airlangga University \\ Surabaya - Indonesia
}

\begin{abstract}
A resilient denture liner is placed in the part of the hollow obturator base that contacts to post hemimaxillectomy mucosa. Replacing the resilient denture liner can makes the hollow obturator has an intimate contact with the mucosa, so it can prevents the mouth liquid enter to the cavum nasi and sinus, also eliminates painful because of using the hollow obturator. Resilient denture liner is a soft and resilient material that applied to the fitting surface of a denture in order to allow a more distribution of load. A case was reported about using the hollow obturator with resilient denture liner on post hemimaxillectomy to overcome these problems.
\end{abstract}

Key words: hollow obturator, resilient denture liner

Correspondence: Michael Josef Kridanto Kamadjaja, c/o: Bagian Prostodonsia, Fakultas Kedokteran Gigi Universitas Airlangga. Jln. Mayjend. Prof. Dr. Moestopo No. 47 Surabaya 60132, Indonesia.

\section{INTRODUCTION}

Maxillofacial Prosthetics is the prosthetic rehabilitation of regions of the head and neck that are missing or defective by means of non-living tissue substitutes. These deficiencies may be due to surgical treatment, trauma, pathology, or congenital malformation.

Intraoral prostheses or obturators are used to reconstruct defects associated with the oral cavity. An obturator prosthesis is used for reconstructing part of the maxilla (upper jaw) and will close oral-nasal openings in the palate, aids breathing/speech and supports oral prosthesis.

Some advantages of obturation are have access to defect area, supports facial profile, no donor site required, restores feelings of normality, builds confidence, to overcome sense of loss and less socially vulnerable. ${ }^{1,2}$

Base of the obturator made of acrylic or metal, and acrylic is usually used as a base of obturator, because it can be adjusted easilly. Obturator usually does not have enough stability, because of lack support and retention, and the weight of the obturator exerts dislodging and rotational forces on the abutment teeth. 3,4

The forces exerted on the artificial teeth, especially during mastication, frequently cause a cantilever effect on the abutment teeth. Greater attention must therefore be paid to the preservation of the abutment teeth. Brown ${ }^{5}$ and Desjardins ${ }^{6}$ have suggested hollow obturator to minimize the weight of the obturator. The hollow obturator showed rapid damping of vibration and minimal displacement of the retainers.

Obturator needs to have maximum support, retention and stability. For this purpose it is necessary to use soft material, e.g resilient denture liner placing in the part of the hollow obturator base that contacts to post hemimaxillectomy mucosa. Replacing the resilient denture liner can makes the hollow obturator has an intimate contact with the mucosa, so it can prevents the liquid enter the nasal cavum and sinus, also eliminates painful using the hollow obturator.

Resilient denture liner is a soft and resilient material that applied to the fitting surface of a denture in order to allow a more equal distribution of load, to permit the mucosal tissues to assume a more normal position. ${ }^{7}$

Resilient denture liner must have general properties such as permanent resiliency, adequate torn resistance, low water sorption and minimal solubility in saliva, aesthetically acceptable, good compatibility with mucosa, odourless and tasteless, high bond strength with denture base and high dimensional stability. ${ }^{8}$

The purpose of this case report is to give information about using hollow obturator with resilient denture liner on post hemimaxillectomy.

\section{CASE}

A 40-years old male patient came to the Prosthodontic clinic due to opening in the left upper jaw, because of post hemimaxillectomy. He was sent by Dr. Soetomo surgery department for an obturator. Teeth in the left upper jaw were extracted during the operation. The remaining teeth in the right upper jaw were from lateral incisor up to second molar. The resection was performed along the left side of the upper jaw and extended across the midline of the maxilla. The right incisive central was also extracted during the maxillectomy.

Radiotherapy and chemotherapy were not performed after the operation. Food and liquid penetrated to nasal 
cavum through defect area during mastication and gave problems to the patient.

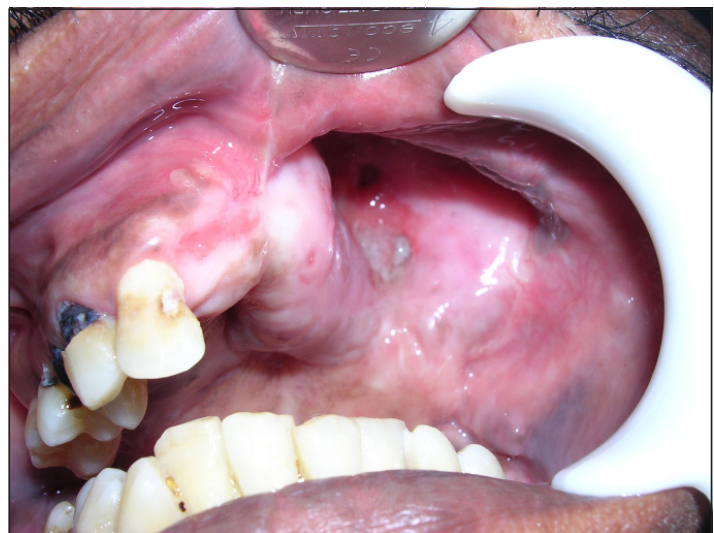

Figure 1. Defect area in the left upper jaw post hemimaxillectomy.

\section{CASE MANAGEMENT}

Impressions were taken to the upper and lower jaw used alginate impression material in order to make a diagnostic cast. Individual tray was fabricated and final impression was performed for the upper jaw. Preparing base and bite wall on the working cast and bite registration was done in the patient's mouth. Working cast and bite registration wax were mounted in the articulator. Artificial teeth were arranged and hollow obturator was made in wax. The hollow obturator was inserted for "try in" the patient's mouth, position and occlusion checked with the natural teeth. Placing back the hollow obturator in the working cast and claps were made in teeth 12,13,15 and 17. Final contour was done and processed with acrylic heat cured. After polishing the hollow obturator was tried in the mouth patient and adjust was done if needed. Intermaxillary record was performed and the hollow obturator was mounted in
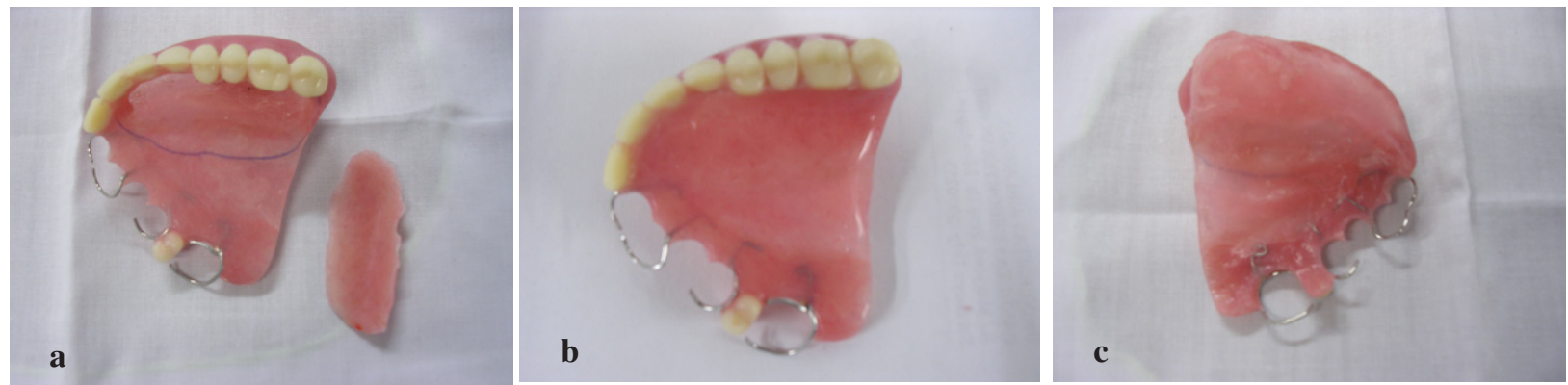

Figure 2. Hollow obturator with upper partial denture.

a: The lid and hollow obturator, b: The lid fixed with self curing acrylic, c: The bulb of the obturator
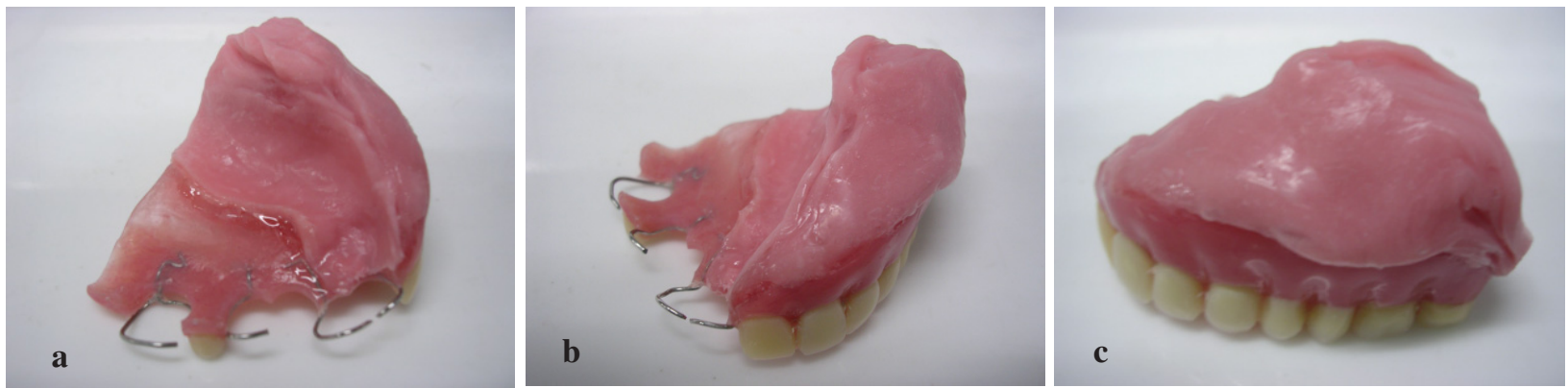

Figure 3 (a, b, c). Replacing hollow obturator with resilient denture liner.
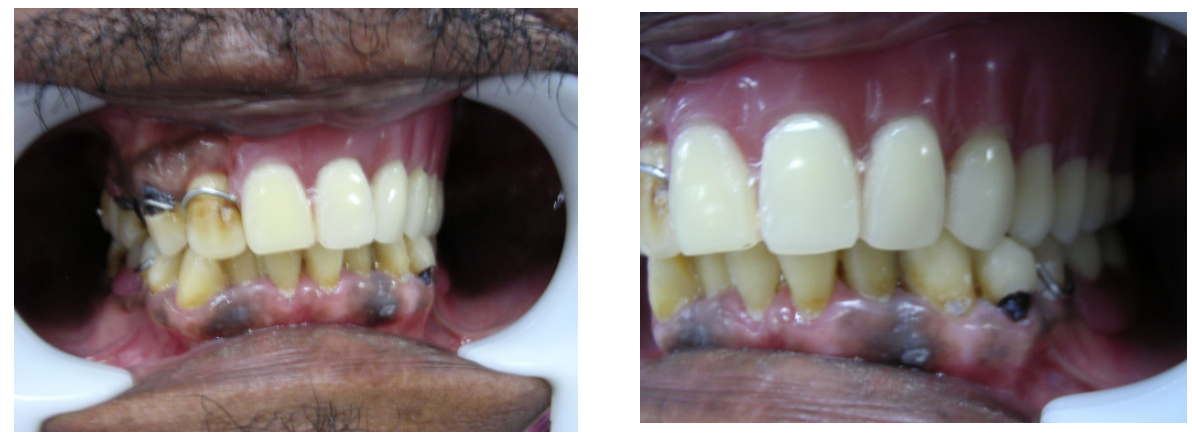

Figure 4 (a, b). Hollow obturator was inserted in the mouth. 
the articulator for selective grinding. The lid of the hollow obturator was fixed with self cured acrylic. Base the hollow obturator that contact to mucosa was roughened with bur and covered with primer solution and waited until it dried. Replacing the resilient denture liner to that area and put the hollow obturator back in the mouth. Patient was ordered to close the mouth and performed muscle trimming. The patient kept closing the mouth until the resilient denture liner hardened. The hollow obturator was taken out and excess material was tidied up with knife and bur. Borderline between acrylic denture liner and hollow obturator base was coated by layer material and dried up. Hollow obturator was inserted in the mouth and ready to use.

\section{DISCUSSION}

The resection in Aramany's class IV was performed across the midline of the maxilla and the right incisive central was extracted during the maxillectomy. Retention and stability of the obturator were obtained from the remaining teeth and mucosa around defect area. Lack of support and retention made the hollow obturator lost its stability, especially during mastication, so frequently cause a cantilever effect on the abutment teeth. ${ }^{2,3}$ Cantilever effect is an rotational and dislodging effect on the abutment teeth, due to of support in the defect area. On the defect area we could also set up artificial teeth, but mastication on this side must be avoided, because lack of tissue support.

In this case four abutment teeth were used as direct retainers and the lateral wall of the hollow obturator was extended to maximize support, retention and stability. Silicone resilient denture liner was placed on the hollow obturator that contacted with the mucosa, so there was an intimate contact between the hollow obturator and the mucosa. The hollow obturator showed rapid damping of vibration and minimal displacement of the retainers. Intimate contact between the two parts could prevent food and liquid enter the nasal cavum and sinus, also eliminate painful. ${ }^{4}$

When the patient came back for control, he reported that there was no pain, the hollow obturator had enough retention and stability, food and liquid did not enter the nasal cavum anymore.

Hollow type obturator was fabricated in this case, so the weight of the obturator could be reduced. The obturator must have minimal weight, stability and good retention. The lid of the hollow obturator was processed with heat- polymerizing acrylic resin and fixed to the bulb with autopolymerizing acrylic resin.

Replacing hollow obturator with resilient denture liner by direct technique method was more simple than indirect technique method, because it does not need complicated procedure in laboratorium. Thickness of the resilient denture liner have to be 2 or $3 \mathrm{~mm}$, that it could have effective function.

Resilient denture liner was a temporary or semipermanent material, because it has some disadvantages such as lost of softness and resiliency, poor bond strenght with denture base, dimensional changes, difficult in cleaning, polishing and finishing. ${ }^{10}$ Denture cleanser had to be used and chosen properly, because denture cleanser had to keep the resilient denture liner in a good condition, so it could be used longer. ${ }^{10}$

It can be concluded that replacing the resilient denture liner can make the hollow obturator has good seal to the mucosa, that it could prevent the mouth liquid entered to the cavum nasi and sinus, also eliminated painful due to the used of the hollow obturator.

\section{REFERENCES}

1. Laney WR. Maxillofacial applications of removable partial prosthodontics. Mc Cracken's removable partial prosthodontics. The CV Mosby Company 1985; 23:443-59.

2. Aramany MA. Basic principles of obturator design for partially edentulous patients. Part I: Clasification. J Prosthet Dent 1978; 40:554-7.

3. Aramany MA. Basic principles of obturator design for partially edentulous patients. Part II: Design principles. J Prosthet Dent 1978 40:656-82.

4. Kobayashi M, Oki M, Ozawa S, Inoue T, Mukohyama H, Takato T, Ohyama T, Taniguchi H. Vibration analysis of obturator prostheses with different bulb height designs. J Med Dent Sci 2002;49:121-8.

5. Brown KE. Peripheral consideration in improving obturator retention. J Prosthet Dent 1969; 20:176-81.

6. Desjardins RP. Obturator prosthesis design for acquired maxillary defects. J Prosthet Dent 1978; 39:424-35.

7. Huggett R. Soft lining materials in prosthetic dentistry: A review. The International Journal of Prosthodontics 1990. p. 477-82.

8. Pesun IJ, Hodges J, Lai JH. Effect of finishing and polishing procedures on the gap width between a denture base resin and two long-term, resilient denture liners. J Prosthet Dent 2002. p. 311-8.

9. Lammie GA, Storer R. A preliminary respon on the resilient denture plastics. J Prosthet Dent 1958; 8:411-24.

10. Hamada T, Murata H, Razak A. Pelapisan gigi tiruan denture lining. Airlangga University Press; 2003. p. 32-44.

11. Schmidt WF, Smith DE. A six-year retrospective study of MolloplastB lined dentures. Part II: Liner serviceability. J Prosthet Dent 1980; 50:459-65. 